\title{
ORGANIC COMPOST CONTROL OF BLIGHT DISEASE OF OKRA (ABELMOSCHUS ESCULENTUS) AND TOMATO (SOLANUM LYCOPERSICUM) PLANTS
}

\author{
$\underline{\text { Habiba Maikudi MUHAMMED }}^{1 *}$, Usman Ibrahim HAMZA ${ }^{1}$, Hadiza ISYAKU $^{1}$, \\ Donadeen OLACHI ${ }^{1}$
}

${ }^{1}$ Department of Biological Sciences, Ibrahim Badamasi Babangida University, Lapai - Niger State.

* Corresponding author. E-mail: habibamaliyu@gmail.com

\begin{abstract}
Organic composts are derived from plant and animal wastes as substrates in the control of blight disease of vegetable crops; tomato (Solanum lycopersicum) and okra (Abelmoschus esculentus) plants were evaluated. Cow dung, sawdust, rice husk, poultry droppings and goat dung were collected from the agricultural research farm Ibrahim Badamasi Babangida university Lapai, Niger State, Nigeria. The organic matter were allowed to decompose watered daily for twenty four days to foster the microbial activities of the composts. Three kilogram $(3 \mathrm{~kg})$ of sterilized topsoil was bulked with the compost at 50 , $100,150,200$ and $250 \mathrm{~g}$ and allowed to decomposed for the period of 10 days respectively. At $200 \mathrm{~g}$ and $250 \mathrm{~g}$ the suppression was significantly different $(\mathrm{P} \leq 0.05)$ than other lower quantities. Goat dung gave the highest suppression of $88.2 \%$ followed by rice husk (85.0\%). At $250 \mathrm{~g}$ it was $99.0 \%, 93.7 \%, 93.7 \%$, $84.0 \%$, and $94.7 \%$ with poultry droppings, rice husk, cow dung, saw dust and goat dung respectively. Goat dung amended soil gave the best blight disease suppression (88.2\%) in okra and poultry droppings gave the best in tomato (99.0\%). A good combination of compost consisting of goat dung and poultry droppings is recommended for the suppression of blight disease in tomato and okra plants.
\end{abstract}

Keywords: blight disease, okra, organic compost, suppression, tomato.

\section{Introduction}

The term organic compost refers to farming practices that may be called agro ecological, sustainable, or ecological; utilize natural (non-synthetic) nutrient-cycling processes; exclude or rarely use synthetic pesticides; and sustain or regenerate soil quality. These practices may include cover crops, manures, compost, crop rotation, intercropping, and biological pest control [LÓPEZ-GONZÁLEZ \& al. 2015].

BOT \& BENITES (2013) highlighted the role of organic compost in sustaining the fertility of soil good for production of vegetables and binding the soil for best performance is obtained on well drained fertile soil with adequate organic matter content. Organic matter are very active and important component of the soil. It is the minerals reservoirs for crop production, it also protects the soil against erosion, supplies the cementing substance for desirable aggregate soil formation and loosen the soil for crop production.

According to MEHTA \& al. (2014) many researches have enhanced the natural ability of compost to suppress diseases by enriching it with specific disease-fighting microorganisms. This amended compost can then be applied to crops infected by known diseases. Researches has shown that tailored compost significantly reduced or replaced the application of pesticides, fungicides and nematicides which could adversely affect water resources, food safety and workers safety [HOITINK \& al. 1997]. The use of amended composts can also be more costeffective than chemical soil treatments such as methyl bromide. Soil treated with compost 
retains irrigation water better, which lowers water costs. Over the years, farmers in Nigeria have employed the use of composted organic materials such as plant debris and animal manure to add nutrient to the soil in other to increase its fertility [MUHAMMAD, 1998]. Indiscriminate use of fungicides and pesticides in controlling seedling blight diseases has polluted both the environment and the plants. The mechanisms of biological control of plant pathogens by antagonistic bacteria and fungi have been the subjects of many studies in the past two decades [JANISIEWICZ \& al. 2000; KILLANI \& al. 2011]. Losses due to blight in an unsprayed fields vary enormously from $5-78 \%$ without the control of disease causing about 32 million dollars [OLANYA \& al. 2009], and 85\% loss in okra annually [AHMED \& al. 2015].

Therefore, this study will focus on addressing the challenges of controlling seedling blight diseases of tomato (Solanum lycopersicum L., family Solanaceae) and okra (Abelmoschus esculentus (L.) Moench, family Malvaceae) crop productions. It will emphasize the use of organic control measures which are eco-friendly and cheap to obtain in order to bring about high yields of the crops.

\section{Materials and methods}

\section{Experimental location}

The experiment was conducted at the Botanical Garden, Department of Biological Sciences, Federal University of Technology, Minna, Niger State, Nigeria on Latitude $9^{\circ} 39^{\prime} 12.38^{\prime \prime} \mathrm{N}$ and Longitude $6^{\circ} 31^{\prime} 24.79^{\prime \prime E}$. The State is situated in latitudes $8^{\circ} 20^{\prime} \mathrm{N}$ and $11^{\circ} 30^{\prime}$ $\mathrm{N}$ and longitude $3^{\circ} 30^{\prime} \mathrm{E}$ and $7^{\circ} 20^{\prime} \mathrm{E}$ which is in the Southern Guinea Savanna ecological zone of Nigeria.

\section{Collection and preparation of organic composts}

Animal and plant wastes were collected from the Agricultural Research farm of the Department of Agriculture, Ibrahim Badamasi Babangida University Lapai, Niger State. The composts were prepared from rice husks, cow dung, chicken droppings and sawdust by adopting the method of ABO \& BADR (2001), LÓPEZ-GONZÁLEZ \& al. (2015). Four (4) sterilized perforated labeled polythene bags were separately filled with $30 \mathrm{~kg}$ each of rice husks, cow dung, poultry droppings and saw dusts. These mixtures of organic wastes were allowed to decomposed, watered daily, and turned at an interval of two days for the period of 24 days.

\section{In-vivo test of soil amended with the composts on blight disease}

Modified method of SHEHU \& al. (2008) was used. Three kilogram (3 kg) of sterilized topsoil was bulked thoroughly with compost at 50,100, 150, 200 and $250 \mathrm{~g}$ per polypots of (20 $\times 30 \mathrm{~cm}$ ). Amended soil was allowed to decompose for the period of 10 days. Three weeks old seedlings of tomato was transplanted into each polypots while okra seeds were sown directly into amended soil. Twenty one (21) days after sowing the seedlings were inoculated with $20 \mathrm{ml}$ spore suspension containing $5 \times 10^{5}$ spores $/ \mathrm{ml}$ of inoculum of fungi and bacteria. Control was prepared without amendment and three replicates were prepared. The seedlings were kept on benchtop at the screen house and were observed and evaluated for the symptoms of blight disease. To determine the influence of amendment on the disease development [COVENTRY $\&$ al. 2005]. The number of seedlings showing the symptoms in each treatment (y), was divided by the total number of plants in the treatment (z) multiply by 100 .

\section{Fungal and bacterial cultures}

Aspergillus niger, Microsporum gypseum, Fusarium oxysporum, Rhizopus nigricans and Penicillium citrinum were previously isolated from blighted okra and tomato plants and the cultures were maintained on potato dextrose agar (PDA) and nutrient agar slants bottles at $37^{\circ} \mathrm{C}$. [RAY \& al. 2000; SWAIN \& RAY, 2009]. 


\section{Inoculation}

Modified method of MUHAMMED \& MUHAMMAD (2013) was used to inoculate five weeks old tomato and okra seedlings growing in oven-sterilized topsoil $(0.5 \mathrm{~cm})$ contained in $15 \mathrm{~cm}$ diameter poly pots were inoculated with the mycelia suspension of the bacterial and fungal isolates. The plants were then placed on top benches in screen house and observed for symptoms of the disease.

Statistical analysis (ANOVA) are performed following a completely randomized design to test the significant effects and means compared using the LSD test $(\mathrm{p} \leq 0.05)$ as outlined by DUNCAN (1955).

\section{Results and discussion}

\section{In-vivo Control of Seedling blight Tomato and Okra using Some Organic Composts}

The results of the percentage blight disease suppression on A. esculentus (Table 1) amended soil with different compost at different quantities per $3 \mathrm{~kg}$ show that as the quantity of amended increased, the disease suppressing also increased. At $200 \mathrm{~g}$ and $250 \mathrm{~g}$ the suppression was significantly different $(\mathrm{P} \leq 0.05)$ than other lower quantities. At $250 \mathrm{~g}$ it was $67.2 \%$ with poultry droppings and $85.0 \%, 83.6 \%, 88.2 \%$, and $88.2 \%$ with rice husk, cow dung, saw dust and goat dung respectively. Goat dung gave the highest suppression of $88.2 \%$ followed by rice husk $(85.0 \%)$. This trend was also followed by the suppression of the disease in tomato. At 250 g it was $99.0 \%, 93.7 \%, 93.7 \%, 84.0 \%$, and $94.7 \%$ with poultry droppings, rice husk, cow dung, saw dust and goat dung respectively (Table 2).

Table 1. Percentage blight disease suppression on Okra grown on soil amended with organic composts

\begin{tabular}{cccccc}
\hline $\begin{array}{l}\text { Quantity of } \\
\text { organic material } \\
\text { g/3 kg soil }\end{array}$ & $\begin{array}{c}\text { Poultry } \\
\text { droppings }\end{array}$ & Rice husks & Cow dung & Saw dusts & Goat dung \\
\hline 50 & $16.40^{\mathrm{a}}$ & $14.80^{\mathrm{a}}$ & $20.60^{\mathrm{a}}$ & $18.60^{\mathrm{a}}$ & $19.80^{\mathrm{a}}$ \\
\hline 100 & $42.20^{\mathrm{b}}$ & $45.80^{\mathrm{b}}$ & $43.40^{\mathrm{b}}$ & $41.20^{\mathrm{b}}$ & $43.00^{\mathrm{b}}$ \\
\hline 150 & $43.40^{\mathrm{b}}$ & $68.00^{\mathrm{c}}$ & $53.00^{\mathrm{c}}$ & $55.40^{\mathrm{c}}$ & $57.80^{\mathrm{c}}$ \\
\hline 200 & $60.60^{\mathrm{c}}$ & $79.00^{\mathrm{d}}$ & $68.20^{\mathrm{c}}$ & $77.80^{\mathrm{d}}$ & $76.60^{\mathrm{d}}$ \\
\hline 250 & $67.20^{\mathrm{d}}$ & $85.00^{\mathrm{e}}$ & $83.60^{\mathrm{d}}$ & $82.20^{\mathrm{e}}$ & $88.20^{\mathrm{e}}$ \\
\hline
\end{tabular}

Values are mean \pm Standard Error of Mean. Mean with the same superscript along row are not significantly different at $\mathrm{P} \geq 0.05$.

Table 2. Percentage blight disease suppression on Tomato grown on soil amended with organic composts

\begin{tabular}{cccccc}
\hline $\begin{array}{l}\text { Quantity of } \\
\text { organic material } \\
\text { g/3 kg soil }\end{array}$ & $\begin{array}{c}\text { Poultry } \\
\text { droppings }\end{array}$ & Rice husks & Cow dung & Saw dusts & Goat dung \\
\hline 50 & $19.00^{\mathrm{a}}$ & $19.00^{\mathrm{a}}$ & $23.00^{\mathrm{a}}$ & $17.70^{\mathrm{a}}$ & $21.00^{\mathrm{a}}$ \\
\hline 100 & $51.33^{\mathrm{b}}$ & $51.70^{\mathrm{b}}$ & $49.70^{\mathrm{b}}$ & $52.00^{\mathrm{b}}$ & $53.30^{\mathrm{b}}$ \\
\hline 150 & $81.33^{\mathrm{c}}$ & $70.00^{\mathrm{c}}$ & $68.30^{\mathrm{c}}$ & $68.00^{\mathrm{c}}$ & $71.00^{\mathrm{c}}$ \\
\hline 200 & $89.00^{\mathrm{d}}$ & $83.30^{\mathrm{d}}$ & $79.70^{\mathrm{d}}$ & $79.70^{\mathrm{d}}$ & $82.00^{\mathrm{d}}$ \\
\hline 250 & $99.00^{\mathrm{e}}$ & $93.70^{\mathrm{e}}$ & $93.70^{\mathrm{e}}$ & $93.70^{\mathrm{e}}$ & $94.70^{\mathrm{e}}$ \\
\hline
\end{tabular}

Values are mean \pm Standard Error of Mean. Mean with the same superscript along row are not significantly different at $\mathrm{P} \geq 0.05$. 
The control of seedling blight disease of tomato and okra have establishing that compost is capable of suppression. Similar report has been reported by [GARRETTE, 1975; CHEN \& al. 1998; PHARAND \& al. 2002] that compost suppress root rot diseases in vegetables. The findings in this study revealed that suppression increases as increase in the quantity of composts. This is in agreement with the reports of SHEHU \& al. (2008) that $80 \%$ disease suppression was achieved with soil amended with composts to control onion disease. Out of all the organic composts used to amend the soil, poultry droppings and goat dung gave the highest suppression of the blight disease of tomato and okra probably because the percentage frequency of the soil borne microbes isolated from them were high. The findings has earlier been reported in the control of seedling blight diseases in vegetables by HULL (2002) and WESTPHAL \& al. (2016).

\section{Conclusions}

The research have revealed that agricultural wastes such as rice husks, cow dung, chicken droppings and sawdusts used as organic material for amended soil are very good in suppression of blight disease in okra while animal droppings used to amend soil produces better result in suppressing blight diseases in tomato.

\section{Notes on contributors}

Habiba Maikudi MUHAMMED is a plant biologist with special interest in plant pathology and plant physiology. Her focuses in the plant diseases and management methods of vegetable crops.

Usman Ibrahim HAMZA is a botanist with special interest in plant mycology.

Hadiza ISYAKU and Donadeen OLACHI are research scientists with the department of Biological Sciences of Ibrahim Badamasi Babangida University Lapai, Niger State, Nigeria. The authors received no financial support from any organization. All authors read and approved the final manuscript.

\section{Acknowledgment}

We are grateful to the entire staffs of the Laboratory of Biological Sciences Department and the Agricultural research farm of Ibrahim Badamasi Babangida University, Lapai, Niger State, Nigeria for providing technical assistance.

\section{Conflict of interests}

The authors declare that there are no conflicts of interest related to this manuscript.

\section{References}

ABO S. \& BADR E. 2001. Antagonistic effects of some compost. Phytopathology. 68: 183-210.

AHMED A. A., ZAKI M. F., SHAFEEK M. R., HELMY Y. I. \& EL-BAKY M. A. 2015. Integrated use of farmyard manure and inorganic Nitrogen fertilizer on growth, yield and quality of Potato (Solanum tuberosum L.). International Journal of Current Microbiology and Applied Sciences. 4(10): 325-349.

BOT A. \& BENITES J. 2013. The importance of soil organic matter. Key to drought resistance soil and sustained food. Food Agriculture Organization Department Soil Bullettin. Rome, Italy: 80.

CHEN Y., INBAR Y. \& HADAR Y. 1998. Composted Agricultural wastes as potting media for ornamental plants. Soil Science. 145(4): 298-303. https://doi.org/10.1097/00010694-198804000-00009

COVENTRY E., NOBLE R., MEAD A. \& WHIPPS J. M. 2005. Suppression of Allium white rot (Sclerotium cepivorum) in different soils using vegetable wastes. European Journal of Plant Pathology. 111(2): 101112. https://doi.org/10.1007/s10658-004-1420-0

DUNCAN D. B. 1955. Multiple Range and Multiple F-Tests. Biometrics. 11: 1-42. https://doi.org/10.2307/3001478 GARRETTE S. 1975. Pathogenic Root-infecting Fungi. Cambridge: Cambridge University Press, 257 pp. 
Habiba Maikudi MUHAMMED \& al.

HOITINK H. A. J., STONE A. G. \& HAN D. Y. 1997. Suppression of plant diseases by composts. HortScience. 32(2): 184-187. https://doi.org/10.21273/HORTSCI.32.2.184

HULL R. 2002. Method combination for document plant virology. In: Proceedings of the $19^{\text {th }}$ Annual International Conference on Research and Development. Academic Press, San Diego. 2002: 44-48.

JANISIEWICZ W. J., TWORKOSKI T. J. \& SHARER C. 2000. Characterizing the mechanism of biological control of postharvest diseases on fruits with a simple method to study competition for nutrients. Phytopathology. 90(11): 1196-1200. https://doi.org/10.1094/PHYTO.2000.90.11.1196

KILLANI A. S., ABAIDOO R. C., AKINTOKUN A. K. \& ABIALA M. A. 2011. Antagonistic effect of indigenous Bacillus subtillis on root/soil borne fungal pathogens of Cowpea. Researcher. 3(3): 11-18.

LÓPEZ-GONZÁLEZ J. A., SUÁREZ-ESTRELLA F., VARGAS-GARCÍA M. C., LÓPEZ M. J., JURADO M. M. \& MORENO J. 2015. Dynamics of bacterial microbiota during lignocellulosic waste composting: studies upon its structure, functionality and biodiversity. Bioresource Technology. 175: 406-416. https://doi.org/10.1016/j.biortech.2014.10.123

MEHTA C. M., PALNI U., FRANKE-WHITTLE I. H. \& SHARMA A. K. 2014. Compost: its role, mechanism and impact on reducing soil-borne plant diseases. Waste Management. 34(3): 607-622. https://doi.org/10.1016/j.wasman.2013.11.012

MUHAMMAD S. 1998. Effects of soil amendments with Rice husks on Fusarium wilt of pepper Capsicum annuum. The Beam: Arts Sciences. 4: 108-112.

MUHAMMED H. M. \& MUHAMMAD S. 2013. In vitro inhibtion of growth of Aspergillus niger, Fusarium oxysporum and Rhizopus nigricans by antagonist Micro-organisms isolated from composted waste. Journal of Phytopathology and Plant Health. 2(1): 83-90.

OLANYA O. M., HONEYCUTT C. W., LARKIN R. P., GRIFFIN T. S., HE Z. \& HALLORAN J. M. 2009. The effect of cropping systems and irrigation management on development of potato early blight. Journal of General Plant Pathology. 75(4): 267-275. https://doi.org/10.1007/s10327-009-0175-z

PHARAND B., CARISSE O. \& BENHAMOU N. 2002. Cytological aspects of compost-mediated induced resistance against Fusarium crown and root rot in tomato. Phytopathology. 92(4): 424-438. https://doi.org/10.1094/PHYTO.2002.92.4.424

RAY R. C., NEDUNZHIYAN M. \& BALAGOPALAN C. 2000. Microorganisms associated with postharvest spoilage of yams. Annals of Tropical Research. 22(1\&2): 31-40.

SHEHU K., SUBERU H. A. \& MAGAJI M. D. 2008. Amelioration of purple blotch disease in Onion (Allium cepa L.) seedlings with organic soil amendments. Nigerian Journal of Basic and Applied Sciences. 16(2): 203-206.

SWAIN M. R. \& RAY R. C. 2009. Biocontrol and other beneficial activities of Bacillus subtilitis isolated from cow dung microflora. Microbiological Research. 164(2): 121-130. https://doi.org/10.1016/j.micres.2006.10.009

WESTPHAL A., KÜCKE M. \& HEUER H. 2016. Soil amendment with digestate from bio-energy fermenters for mitigating damage to Beta vulgaris subspp. by Heterodera schachtii. Applied Soil Ecology. 99: 129-136. https://doi.org/10.1016/j.apsoil.2015.11.019

How to cite this article:

MUHAMMED H. M., HAMZA U. I., ISYAKU H. \& OLACHI D. 2021. Organic compost control of blight disease of okra (Abelmoschus esculentus) and tomato (Solanum lycopersicum) plants. J. Plant Develop. 28: 123-127. https://doi.org/10.47743/jpd.2021.28.1.872 